\title{
An in vitro based investigation into the cytotoxic effects of D-amino acids
}

\author{
SANAA K. BARDAWEEL ${ }^{1 *}$ \\ RANA ABU-DAHAB ${ }^{2}$ \\ NOUR F. ALMOMANI \\ ${ }^{1}$ Department of Pharmaceutical Sciences \\ Faculty of Pharmacy, The University of \\ Jordan, Amman 11942, Jordan \\ ${ }^{2}$ Department of Biopharmaceutics and \\ Clinical Pharmacy, Faculty of Pharmacy \\ The University of Jordan, Amman 11942 \\ Jordan
}

Accepted July 16, 2013
In the present study, cytotoxic effects of D-Ala, D-Pro and D-Lys are demonstrated. In an effort to study the possible mechanisms of the observed cytotoxicity, catalase activity, $\mathrm{H}_{2} \mathrm{O}_{2}$ generation, and apoptotic activity were measured in HeLa and MCF-7 cell lines. Although D-Lys is a poor substrate for DAO and therefore low $\mathrm{H}_{2} \mathrm{O}_{2}$ was detected, it was shown to provoke severe impairment of cellular integrity and survival. Interestingly, a very good substrate for DAO, such as D-Pro, did not substantially reduce cell viability. On the other hand, a moderate substrate for DAO, represented by D-Ala, was shown to moderately trigger toxicity in the tested cell lines. Although a correlation between the in vitro cytotoxicity of D-amino acids and the amount of $\mathrm{H}_{2} \mathrm{O}_{2}$ produced was absent, there was a good agreement between the ability of D-amino acids to trigger apoptosis and to provoke toxicity. Our results indicate that the toxicity of D-amino acids does not appear to be solely mediated by $\mathrm{H}_{2} \mathrm{O}_{2}$. Therefore, we hypothesize that other possible contributing apoptosis-mediated pathways might cause the observed toxicity.

Keywords: D-amino acids, toxicity, HeLa cells, MCF7 cells, catalase, apoptosis, oxidative stress

Numerous innovations in analytical methods have demonstrated the presence of D-amino acids in eukaryotes, including mammals (1-3). The most abundant D-amino acids in mammals are D-serine and D-aspartate (4). D-alanine is also present in mammals at moderate levels $(4,5)$. Recently, physiological roles of these D-amino acids in humans have been reported. For example, D-serine has been found to modulate the activity of $N$-methyl-D-aspartate (NMDA) receptor in the brain (6). It is postulated that D-serine binds to the coagonist binding site of the MDA receptor, which is involved in numerous physiological and pathological processes, including synaptic plasticity, learning, memory, neuronal cell migration, and neural diseases $(7,8)$. Furthermore, D-aspartate has

* Correspondence; e-mail: S.Bardaweel@ju.edu.jo 

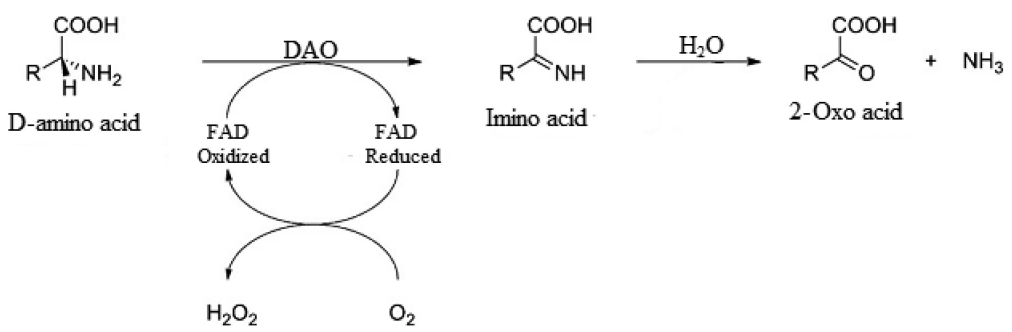

Fig. 1. The D-amino-acid oxidase-catalyzed reaction. D-amino acid is oxidized to an imino acid with concurrent reduction of flavin adenine dinucleotide (FAD). The reduced FAD is subsequently oxidized while molecular oxygen is reduced to hydrogen peroxide. Consequently, the imino acid undergoes a non-enzymatic hydrolysis to the corresponding 2-oxo acid and ammonia.

been detected in nervous and endocrine tissues and is believed to be involved in the regulation of hormone release $(9,10)$, melatonin $(11)$ and testosterone syntheses $(12,13)$. Additionally, the presence of free D-aspartate in the nuclei of mammalian tissues may suggest a role of D-aspartate in gene expression (14).

In mammals, D-amino acid oxidase (DAO) and D-aspartate oxidase (DAspO) catalyze the oxidative deamination of $\mathrm{D}$-amino acids into the corresponding $\alpha$-keto acids. D-amino acid oxidase was the first enzyme discovered in mammals (15). It has been found that DAO contains flavin adenine dinucleotide (FAD) as a prosthetic group and catalyzes the oxidative deamination of D-amino acids according to the reaction mechanism shown in Figure 1. During the initial step of catalysis, oxidation of D-amino acid into the imino acid and concomitant reduction of FAD occur. Subsequently, the reduced FAD is oxidized by oxygen to release hydrogen peroxide, and the imino acid is non-enzymatically hydrolyzed to produce the corresponding 2-oxo acid and ammonia $(15,16)$. DAO has a wide range of substrate specificity and metabolizes a large number of neutral and basic D-amino acids. Similarly, D-aspartate oxidase has FAD as a prosthetic group and catalyzes the oxidative deamination of acidic D-amino acids such as D-aspartate and D-glutamate, to produce the corresponding 2-oxo acid, hydrogen peroxide and ammonia $(15,16)$.

A major characteristic of DAO and DAspO is their high specificity towards the D-isomers of amino acids; they are almost inactive towards the corresponding L-isomers. Broad substrate specificity of DAO is a plus when considering the overall concentration of the D-isomer of amino acids in food and drinks. The D-isomers of proline, methionine, isoleucine, alanine, valine and phenylalanine are good substrates for DAO (17). Nevertheless, D-ornithine, cis-4-hydroxy-D-proline, $N$-acetyl-D-Ala and D-Lys are oxidized at very low rates by DAO (17).

Although potential toxicity has been linked to D-amino acids, the fundamental mechanism by which toxicity occurs is not fully understood. In animal studies, administration of D-amino acids to rats and chicks resulted in growth inhibition. In addition, D-amino acids accumulation in certain tissues caused serious damage such as suppression of the synthesis of glutamate oxaloacetate transaminase, glutamic pyruvic transaminase, and lactate dehydrogenase (18). It has been suggested that the toxicity of D-amino 
acids arises from the oxidative damage to cells by $\mathrm{H}_{2} \mathrm{O}_{2}$ formed upon the oxidation of D-amino acids (19). Supporting this suggestion, $\mathrm{H}_{2} \mathrm{O}_{2}$ appears to readily cross cellular membranes and cause oxidative damage to DNA, proteins and lipids (20-22). Furthermore, $\mathrm{H}_{2} \mathrm{O}_{2}$ has been found to induce apoptosis of tumor cells in vitro via activation of the Caspase cascade (23).

To assess the in vitro cytotoxicity of D-amino acids and to gain further insights into the molecular mechanisms that provoke the observed cytotoxicity, we investigated the cytototoxic effects and possible mechanisms of cytoxicity of three D-amino acids, D-alanine, D-proline and D-lysine, using several cell line models.

\section{EXPERIMENTAL}

\section{Mammalian cell lines and cell culture}

The cell lines under investigation were human breast adenocarcinoma MCF7, MDA-MB-231 and MDA-MB-453 cell lines, the human ductal breast epithelial tumor cell line T47D, human pancreatic carcinoma MIA PaCa-2 cell line, T-cell leukemia HPB-MLT cell line, human Burkitt's lymphoma Raji cell line, EBV-negative Burkitt's lymphoma $\mathrm{BJAB}$ cell line, the human colon adenocarcinoma Caco-2 cell line, and human epithelial carcinoma HeLa cell line. Cell lines were cultured in high glucose Dulbecco's modified eagle medium (DMEM) (Invitrogen, USA) containing $10 \%$ heat inactivated fetal bovine serum (HI-FBS) (Invitrogen), $2 \mathrm{mmol} \mathrm{L}^{-1}$ L-glutamine, $50 \mathrm{U} \mathrm{mL}^{-1}$ penicillin and $50 \mu \mathrm{g}$ $\mathrm{mL}^{-1}$ streptomycin. Cell lines were maintained at $37^{\circ} \mathrm{C}$ in a $5 \% \mathrm{CO}_{2}$ atmosphere of $95 \%$ humidity. The cells were passaged weekly, and the culture medium was changed twice a week. According to their growth profiles, optimal plating densities were determined.

\section{Cell proliferation by MTS assay}

MTS assays were carried out using the CellTiter 96 aqueous one solution cell proliferation assay (Promega Co., USA) according to the manufacturer's protocol. The yellow tetrazolium dye [MTS, 3-(4,5-dimethylthiazol-2-yl)-5-(3-carboxymethoxyphenyl)-2-(4-sulfophenyl)- $2 \mathrm{H}$-tetrazolium, inner salt] was reduced by metabolically active cells into the intracellular purple formazan product that is soluble in the tissue culture medium (24). The conversion of MTS into the aqueous soluble formazan product was accomplished by dehydrogenase enzymes found in metabolically active cells (24). The quantity of formazan product as measured by the amount of $490 \mathrm{~nm}$ absorbance was directly proportional to the number of living cells in the culture. To ensure exponential growth throughout the experimental period, as well as a linear relationship between absorbance at $490 \mathrm{~nm}$ and cell number when analyzed by the MTS assay, the following densities were used for each cell line: $1 \times 10^{4}$ cells per well for the MCF-7, MDA-MB-231, MDA-MB-453, T47D, MIA PaCa-2, Caco-2 and HeLa cell lines, and $2 \times 10^{4}$ cells per well for the HPB-MLT, BJAB and Raji cell lines. 
D-amino acids cytotoxicity in MCF-7, MDA-MB-231, MDA-MB-453, T47D, MIA PaCa-2, Caco-2, and HeLa cell lines

For the assay, cells were washed three times with phosphate buffered saline (PBS). PBS was then decanted and cells were detached with the non-enzymatic cell dissociation complex (Sigma Chemical Co., USA). Medium was added to a volume of $10 \mathrm{~mL}$. The cell suspension was centrifuged at $1000 \times \mathrm{g}$ at $4{ }^{\circ} \mathrm{C}$ for $10 \mathrm{~min}$ and the pellet was re-suspended in $10 \mathrm{~mL}$ of medium to make a single cell suspension. Cells were counted using the trypan blue exclusion method and seeded into 96-well plates at the desired densities. A hundred $\mu \mathrm{L}$ of cell suspension was seeded and incubated per well to allow for cell attachment. After $24 \mathrm{~h}$, the cells were treated with D-amino acids. Each D-amino acid solution, at a concentration of $1 \mathrm{~mol} \mathrm{~L}^{-1}$, was prepared in BPS and passed through a $0.02-\mu \mathrm{m}$ filter, then further diluted in the medium to produce the desired concentration. Cells were treated with various concentrations of each D-amino acid in four triplicates. Concentration ranges were $10-150 \mathrm{mmol} \mathrm{L}^{-1} \mathrm{D}-\mathrm{Ala}, 10-250 \mathrm{mmol} \mathrm{L}^{-1} \mathrm{D}-\mathrm{Pro}$, and 1-60 mmol $\mathrm{L}^{-1}$ D-Lys Treated cells were incubated in a $37{ }^{\circ} \mathrm{C} 5 \% \mathrm{CO}_{2}$ incubator for 24 or $48 \mathrm{~h}$. At the end of the exposure time, MTS assays were carried out as previously described. The absorbance at $490 \mathrm{~nm}$ was read on a plate reader (Tecan Group Ltd., Switzerland). Control wells were prepared under the same experimental conditions but without the treatment with D-amino acids.

\section{D-amino acids cytotoxicity in HPB-MLT, BJAB and Raji cell lines}

Viable cells were counted and diluted with medium to give a final density of $2 \times 10^{4}$ cells per well. A hundred $\mu \mathrm{L}$ of cell suspension per well was seeded into 96-well plates. After $24 \mathrm{~h}$, the cells were treated with D-amino acids. Cells were treated with various concentrations of each D-amino acid in four triplicates. The plates were incubated for 24 or $48 \mathrm{~h}$ at $37{ }^{\circ} \mathrm{C} 5 \% \mathrm{CO}_{2}$. Cell viability was measured using the MTS assay as previously described. Control wells without the treatment with $D$-amino acid were prepared under the same experimental conditions.

\section{Preparation of cell lysates}

For each assay, HeLa and MCF-7 cells were grown in six-well plates. When the cells reached $80 \%$ confluence, they were incubated with either $50 \mathrm{mmol} \mathrm{L}^{-1} \mathrm{D}-\mathrm{Ala}, 50 \mathrm{mmol}$ $\mathrm{L}^{-1} \mathrm{D}$-Pro or $10 \mathrm{mmol} \mathrm{L}^{-1} \mathrm{D}$-Lys for $24 \mathrm{~h}$ at $37^{\circ} \mathrm{C}$ in $95 \%$ air, $5 \% \mathrm{CO}_{2}$. At the end of the treatment, cells were harvested with the non-enzymatic cell dissociation complex before centrifuging at $1000 \times \mathrm{g}$ at $4{ }^{\circ} \mathrm{C}$ for $5 \mathrm{~min}$. The pellets were re-suspended in $2 \mathrm{~mL}$ of solution consisting of $50 \mathrm{mmol} \mathrm{L}^{-1}$ phosphate buffer ( $\mathrm{pH} 7.0$ ), then lysed by several freezing-thawing cycles. The lysates were centrifuged at $3000 \times g$ at $4{ }^{\circ} \mathrm{C}$ for $5 \mathrm{~min}$, and the supernatants were frozen at $-20{ }^{\circ} \mathrm{C}$ until used. Protein concentrations of the supernatants were determined by the Bio-Rad protein assay (Bio-Rad Inc., USA) using bovine serum albumin (BSA) as a standard. 


\section{Catalase assay}

Catalase activity was determined as described previously by Aebi (25). The working solution was prepared by adding $\mathrm{H}_{2} \mathrm{O}_{2}$ to phosphate buffer. First, $50 \mathrm{mmol} \mathrm{L}-1$ phosphate buffer ( $\mathrm{pH} 7.0$ ) and $30 \mathrm{mmol} \mathrm{L}^{-1} \mathrm{H}_{2} \mathrm{O}_{2}$ solutions were prepared. Then, $0.3 \mathrm{~mL}$ of 30 mmol L-1 $\mathrm{H}_{2} \mathrm{O}_{2}$ solution was added into $100 \mathrm{~mL}$ of $50 \mathrm{mmol} \mathrm{L}^{-1}$ phosphate buffer $(\mathrm{pH}$ 7.0) to yield the working solution. Using phosphate buffer ( $50 \mathrm{mmol} \mathrm{L}^{-1}, \mathrm{pH} 7.0$ ) as a blank, absorbance of the working solution at $240 \mathrm{~nm}$ was measured and then adjusted to lie between 1.15 and 1.20 by diluting with buffer or adding more $\mathrm{H}_{2} \mathrm{O}_{2}$. When the enzyme assay was undertaken, $0.4 \mathrm{~mL}$ of the cell homogenate was added to $3.6 \mathrm{~mL}$ phosphate buffer ( $50 \mathrm{mmol} \mathrm{L}^{-1}, \mathrm{pH}$ 7.0) to yield the assay solution. In the test cuvette, $1 \mathrm{~mL}$ of the working solution was added to the assay solution and the decrease of absorbance at $240 \mathrm{~nm}$ was recorded over a reaction course of $2 \mathrm{~min}$. In a blank cuvette, $1 \mathrm{~mL}$ of phosphate buffer ( $50 \mathrm{mmol} \mathrm{L}^{-1}, \mathrm{pH} 7.0$ ) was added to $2 \mathrm{~mL}$ of the assay solution and the change in absorbance at $240 \mathrm{~nm}$ was recorded over a reaction course of $2 \mathrm{~min}$.

\section{$\mathrm{H}_{2} \mathrm{O}_{2}$ determination}

$\mathrm{H}_{2} \mathrm{O}_{2}$ released by control cells or by cells ( $5 \times 10^{6}$ cells) treated with either $50 \mathrm{mmol}$ $\mathrm{L}^{-1} \mathrm{D}$-Ala, $50 \mathrm{mmol} \mathrm{L}^{-1}$ D-Pro or $10 \mathrm{mmol} \mathrm{L}^{-1} \mathrm{D}$-Lys for $24 \mathrm{~h}$ was measured with an Amplex ${ }^{\circledR}$ Red hydrogen peroxide/peroxidase assay kit (Invitrogen) according to the manufacturer's protocol. The reaction mixture containing $50 \mu \mathrm{mol} \mathrm{L}^{-1}$ Amplex ${ }^{\circledR}$ Red reagent and $0.1 \mathrm{U} \mathrm{mL}^{-1}$ horseradish peroxidase in Krebs-Ringer phosphate was prepared and incubated at $37^{\circ} \mathrm{C}$ for $10 \mathrm{~min}$. After D-amino acid treatment for $6 \mathrm{~h}, 100 \mu \mathrm{L}$ of the reaction mixture was added to each microplate well and incubated at $37^{\circ} \mathrm{C}$ for $30 \mathrm{~min}$ before absorbance at $\sim 560 \mathrm{~nm}$ was read on a plate reader. To correct for background absorbance, the value derived from the untreated control was subtracted for each point.

\section{Cell death detection ELISAplus assay}

The cell death detection ELISAplus assay (Roche, USA) was used to evaluate the apoptotic activity in the cells after incubation with either $50 \mathrm{mmol} \mathrm{L}^{-1} \mathrm{D}-\mathrm{Ala}, 50 \mathrm{mmol}$ $\mathrm{L}^{-1} \mathrm{D}$-Pro or $10 \mathrm{mmol} \mathrm{L}-1$ D-Lys for a period of $24 \mathrm{~h}$. After treatment, the cells were lysed to release cytoplasmic histone associated-DNA-fragments that indicate that apoptosis activity. Absorbance was read at $405 \mathrm{~nm}$. Higher absorbance correlated to increased apoptosis. Negative controls were obtained from untreated cells under the same experimental conditions.

\section{RESULTS AND DISCUSSION}

\section{In vitro cytotoxicity of D-amino acids}

Cytotoxic effects of D-Ala, D-Pro and D-Lys were examined via an in vitro system using several cancerous cell lines, as described in the Experimental section. Our choice of D-amino acids was based on their susceptibility to be metabolized by DAO. D-Pro 
Table I. Percentage cell survival following exposure to D-amino acids

\begin{tabular}{lccc}
\hline \multirow{2}{*}{ Cell line } & \multicolumn{3}{c}{ D-amino acid } \\
\cline { 2 - 4 } & D-Pro $^{\mathrm{a}}$ & D-Ala $^{\mathrm{a}}$ & D-Lys $^{\mathrm{b}}$ \\
\hline HeLa & $86 \pm 2$ & $63 \pm 2$ & $33 \pm 1$ \\
MCF7 & $85 \pm 3$ & $78 \pm 3$ & $37 \pm 2$ \\
T47D & $83 \pm 3$ & $76 \pm 3$ & $28 \pm 2$ \\
MD A-MB-231 & $86 \pm 6$ & $57 \pm 4$ & $29 \pm 3$ \\
MDA-MB-453 & $82 \pm 3$ & $60 \pm 3$ & $26 \pm 3$ \\
MI A PaCa-2 & $92 \pm 4$ & $86 \pm 4$ & $69 \pm 3$ \\
HPB-MLT & $95 \pm 1$ & $87 \pm 1$ & $77 \pm 4$ \\
Raji & $94 \pm 2$ & $88 \pm 2$ & $71 \pm 3$ \\
BJAB & $93 \pm 2$ & $87 \pm 1$ & $73 \pm 6$ \\
Caco-2 & $89 \pm 3$ & $79 \pm 3$ & $41 \pm 3$ \\
\hline
\end{tabular}

Mean value $\pm \operatorname{SD}(n=12)$.

a $c=50 \mathrm{mmol} \mathrm{L}^{-1}$

${ }^{\mathrm{b}} \mathrm{c}=10 \mathrm{mmol} \mathrm{L}^{-1}$

represents an optimal substrate for DAO with a high turnover rate (17) while D-Ala represents a moderate substrate for DAO with an intermediate turnover rate (17). However, D-Lys represents a very poor substrate for DAO with a low turnover rate (17). According to our results, $10 \mathrm{mmol} \mathrm{L}^{-1} \mathrm{D}$-Lys and $50 \mathrm{mmol} \mathrm{L}^{-1} \mathrm{D}$-Ala exhibited remarkable cytotoxic effects when incubated for $24 \mathrm{~h}$ (Table I), or $48 \mathrm{~h}$ (data not shown), with the cell lines under investigation, whereas $50 \mathrm{mmol} \mathrm{L}^{-1}$ D-Pro exhibited a minimal cytotoxic ef-

Table II. $\mathrm{IC}_{50}$ values of D-amino acids

\begin{tabular}{lrc}
\hline \multirow{2}{*}{ Cell line } & \multicolumn{2}{c}{$I C_{50}\left(\mathrm{mmol} \mathrm{L}^{-1}\right)$} \\
\cline { 2 - 3 } & D-Ala & D-Lys \\
\hline HeLa & $73 \pm 6$ & $18 \pm 3$ \\
MCF7 & $73 \pm 6$ & $22 \pm 4$ \\
T47D & $74 \pm 4$ & $17 \pm 5$ \\
MDA-MB-231 & $66 \pm 7$ & $15 \pm 2$ \\
MDA-MB-453 & $52 \pm 2$ & $14 \pm 3$ \\
MIA PaCa-2 & $75 \pm 5$ & $33 \pm 6$ \\
HPB-MLT & $102 \pm 9$ & $27 \pm 5$ \\
Raji & $85 \pm 7$ & $28 \pm 5$ \\
BJAB & $98 \pm 5$ & $29 \pm 4$ \\
Caco-2 & $77 \pm 7$ & $23 \pm 2$ \\
\hline
\end{tabular}

Mean value $\pm \mathrm{SD}(n=12)$. 
fect under the same experimental conditions (Table I). Concentration-dependent cytotoxicity was observed when D-Ala and D-Lys were incubated for $24 \mathrm{~h}$ with the cell lines under investigation and thus $I C_{50}$ values were determined (Table II). To confirm that the toxicity observed with D-amino acids was specific to D-enantiomer and not to L-enantiomer, studies under conditions where cells were treated with various concentrations of L-Ala, L-Pro, or L-Lys were undertaken. Our results indicate that toxicity is only observed for D-isomer but not L-isomer at concentrations up to $150 \mathrm{mmol} \mathrm{L}^{-1}$ of amino acids (data not shown).

Several potentially harmful byproducts of normal cellular metabolism directly influence cellular functions and survival (26). Despite the fact that such harmful byproducts are vital for signal transduction pathways (27) and reduction-oxidation status (26), overproduction of these highly reactive metabolites can initiate lethal chain reactions that ultimately lead to impairment of cellular integrity and survival (26). Although the toxicity of D-amino acids has been recognized, the reason for their toxicity has not been revealed yet. Several mechanisms were proposed to explain the toxicity associated with D-amino acids in eukaryotes. The most broadly recognized pathway of D-amino acids' toxicity in eukaryotes appears to be related to the oxidative damage to cells by $\mathrm{H}_{2} \mathrm{O}_{2}$ that occurs upon the oxidation of D-amino acids by DAO and/or DAspO (19). In an effort to study the mechanism of cytotoxicity, the catalase assay and direct $\mathrm{H}_{2} \mathrm{O}_{2}$ determination were undertaken, as described below.

\section{Catalase activity}

HeLa and MCF-7 cell lines were selected as representative cell lines to investigate the mechanisms of the observed cytotoxicity of D-amino acids. Around 5x106 HeLa cells

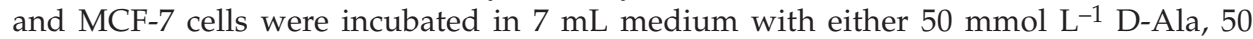
mmol L ${ }^{-1}$ D-Pro, or $10 \mathrm{mmol} \mathrm{L}^{-1} \mathrm{D}$-Lys separately for $24 \mathrm{~h}$. The cells were washed with PBS and collected for the catalase assay. After addition of the $\mathrm{H}_{2} \mathrm{O}_{2}$ working solution, the enzyme activity was determined by following the reduction of absorbance of cell homogenate over two minutes. Comparing the specific activities (international unit/protein concentration) of catalase, it is noticeable that catalase activities of HeLa cells and MCF-7 cells were significantly increased, about 10- and 8-fold, respectively, compared to

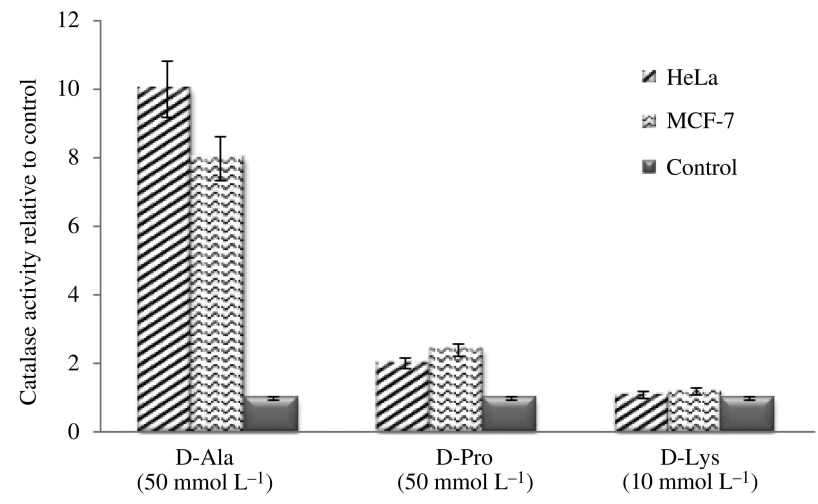

Fig. 2. Catalase activity following D-amino acid treatment for $24 \mathrm{~h}$. Data represent the mean \pm SD $(n=3)$ from blots. 
the untreated control, in response to the addition of $50 \mathrm{mmol} \mathrm{L}^{-1} \mathrm{D}$-Ala (Fig. 2). Nevertheless, only a 2-fold increase of catalase activity in HeLa cells and a 2.4-fold increase in MCF-7 cells were observed when treated with $50 \mathrm{mmol} \mathrm{L}^{-1} \mathrm{D}-$ Pro under the same experimental conditions. In contrast, compared to the untreated controls of each cell line, only a 10-15\% increase of catalase activity in both HeLa cells and MCF-7 cells was observed when treated with $10 \mathrm{mmol} \mathrm{L}-1$ D-Lys.

\section{$\mathrm{H}_{2} \mathrm{O}_{2}$ determination}

To support the $\mathrm{H}_{2} \mathrm{O}_{2}$-mediated toxicity pathway of D-amino acids and to establish a clear correlation between the cytotoxic effect of D-amino acids and their DAO turnover rate, we investigated the cytotoxic effects of various D-amino acids, including a good substrate for DAO with a high turnover rate (17) represented by D-Pro, a moderate substrate for DAO with an intermediate turnover rate (17) represented by D-Ala and a very modest substrate for DAO with a low turnover rate represented by D-Lys (17).

The amount of $\mathrm{H}_{2} \mathrm{O}_{2}$ released into the culture medium after a $6 \mathrm{~h}$ treatment was monitored in HeLa and MCF-7 cell lines. After the 50 mmol L-1 D-Ala treatment, $\mathrm{H}_{2} \mathrm{O}_{2}$ release increased the 13- and 10-fold compared to the untreated cells of HeLa and MCF-7 cells, respectively. Nevertheless, $\mathrm{H}_{2} \mathrm{O}_{2}$ release with $50 \mathrm{mmol} \mathrm{L}^{-1}$ D-Pro was enhanced only 2-3-fold relative to the untreated cells. Interestingly, $\mathrm{H}_{2} \mathrm{O}_{2}$ release with $10 \mathrm{mmol} \mathrm{L}^{-1}$ D-Lys was almost about the same as that of untreated cells (Fig. 3). Our results indicate that D-Lys, which is a poor substrate for DAO, and therefore low $\mathrm{H}_{2} \mathrm{O}_{2}$ is produced (Fig. 3), exhibited the highest toxicity amongst the tested D-amino acids (Tables I and II). On the other hand, D-Pro, which has a high DAO turnover rate, and thus high $\mathrm{H}_{2} \mathrm{O}_{2}$ level is expected to be produced, appears to exhibit minimal toxicity to most cell lines under investigation (Tables I and II).

In agreement with this, the catalase activity measured in HeLa and MCF-7 cell lines increased correspondingly to $\mathrm{H}_{2} \mathrm{O}_{2}$ produced after the D-amino acid treatment (Figs. 2 and 3). Catalase plays a central function in the antioxidant defense of the organism, as $\mathrm{H}_{2} \mathrm{O}_{2}$ is degraded to $\mathrm{H}_{2} \mathrm{O}$ (28). As shown in Fig. 2, D-Ala treatment resulted in an 8-10

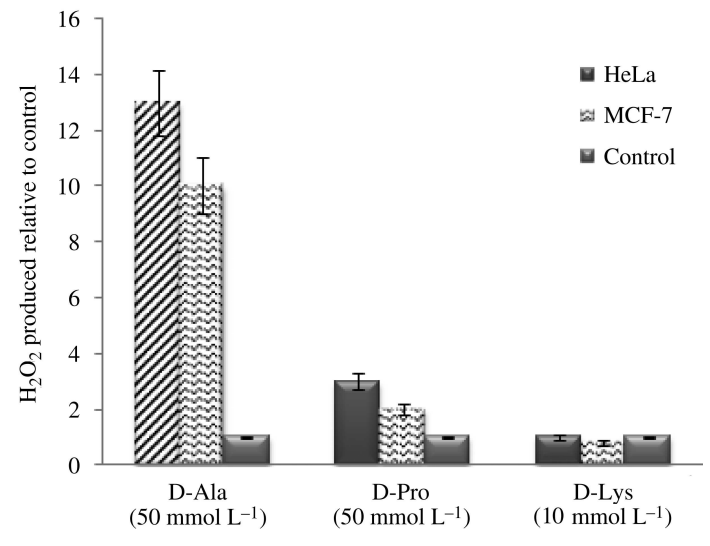

Fig. 3. $\mathrm{H}_{2} \mathrm{O}_{2}$ Accumulation in culture medium after D-amino acid treatment for $6 \mathrm{~h}$. Data represent the mean \pm SD $(n=3)$ from blots. 
fold increase in catalase activity; nonetheless, significant accumulation of $\mathrm{H}_{2} \mathrm{O}_{2}$ occured (Fig. 3), which might outstrip the scavenging capacity of catalase and resulted in the observed toxicity. However, although the treatment with D-Lys altered neither the catalase activity nor the amount of $\mathrm{H}_{2} \mathrm{O}_{2}$ produced, it resulted in considerable toxicity, which was possibly not mediated by $\mathrm{H}_{2} \mathrm{O}_{2}$. Interestingly, a good substrate for DAO such as D-Pro showed only a 2-3 fold increase in catalase activity as well as in the amount of $\mathrm{H}_{2} \mathrm{O}_{2}$ released. As indicated by our results, D-Pro did not exhibit a noteworthy cytotoxicity compared to D-Ala or D-Lys.

\section{Cell death detection ELISAplus assay}

In an attempt to explore the possible mechanisms of cytotoxicity observed with D-Lys and D-Ala, we evaluated the apoptotic activities in HeLa and MCF-7 cells after treatment with D-amino acids. A cell death detection ELISAplus assay was used to verify whether the significant decrease in cell growth observed after the treatment with D-amino acids was the result of enhanced apoptosis in HeLa and MCF7 cell lines. Fig. 4 shows that maximum increase in apoptotic activity was observed after the treatment with $10 \mathrm{mmol} \mathrm{L}^{-1} \mathrm{D}$-Lys followed by $50 \mathrm{mmol} \mathrm{L}^{-1} \mathrm{D}$-Ala treatment in both cell lines. In contrast, D-Pro treatment did not appear to significantly increase the apoptotic activity in both cell lines. Interestingly, the apoptotic activities, measured by determination of DNA fragmentation, were in good agreement with the cytotoxic effects exhibited by D-Lys and D-Ala (Fig. 4).

Based on several pieces of evidence, it has recently been suggested that D-amino acids' toxicity is directly related to the formation of D-aminoacyl-tRNA. Under tight regulations of cellular protein syntheses and modifications, D-amino acids are usually not incorporated into protein structures. High substrate selectivity towards L-amino acids by aminoacyl-tRNA synthetases largely contributes to the preferential incorporation of L-amino acids in protein structures (29). However, it has been observed that Escherichia coli and Bacillus subtilis tyrosyl-tRNA synthetases can potentially catalyze the formation of D-tyrosyl-tRNA ${ }^{\mathrm{Tyr}}$ to the same extent as with L-enantiomer (30). Interestingly, extracts

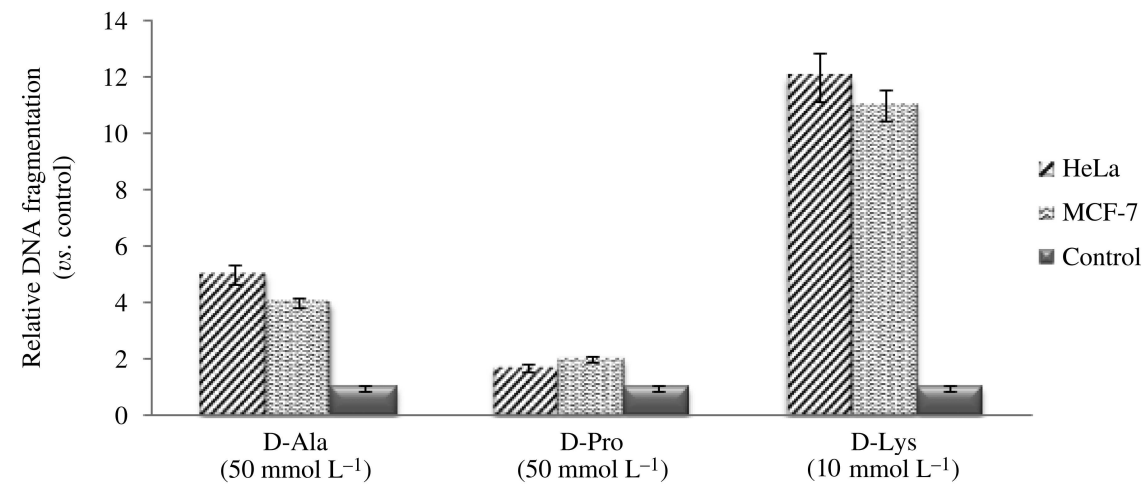

Fig. 4. Apoptotic effect after D-amino acid treatment for $24 \mathrm{~h}$. Data represent the mean $\pm \mathrm{SD}$ $(n=3)$ from blots. 
of E. coli, yeast, rabbit reticulocytes, and rat liver were shown to have an enzyme activity capable of accelerating the hydrolysis of the ester linkage of D-Tyr-tRNA to release free tRNA and D-tyrosine (31).

The fate of D-aminoacyl-tRNA had never been studied previously. However, Dedkova et al. (32) demonstrated that D-methionine and D-phenylalanine charged on aminoacyl-tRNA were incorporated into proteins in vitro, suggesting that the toxicity of D-amino acids might arise from the mis-incorporation of D-amino acids in protein structures, resulting in the formation of functionless proteins.

Taken together, as demonstrated by our results, the toxicity of D-amino acids does not appear to be solely mediated by $\mathrm{H}_{2} \mathrm{O}_{2}$, as previously suggested. Using several measures, our results show that a correlation between the in vitro cytotoxicity of D-amino acids and the amount of $\mathrm{H}_{2} \mathrm{O}_{2}$ produced is absent, suggesting the presence of other possible contributing apoptosis-mediated pathways of toxicity. Ongoing studies that are attempting to unravel the correlation between the D-amino acids' toxicity and the formation of mis-folded proteins should shed light on other possible toxicity pathways.

\section{CONCLUSIONS}

In conclusion, in an attempt to study the possible mechanisms of the observed cytotoxicity of D-amino acids, we reported here the in vitro cytotoxic effects of D-amino acids with variable DAO turnover rates. Our results reveal that the oxidative damage which results from $\mathrm{H}_{2} \mathrm{O}_{2}$ production by DAO upon the oxidative deamination of D-amino acids, may not be the only mechanism contributing to toxicity. These findings may lend further support to the validity of the suggested hypothesis of D-amino acid mis-incorporation in protein structures, resulting in the formation of functionless proteins, hence, toxicity.

\section{REFERENCES}

1. D. L. Kirschner and T. K. Green, Separation and sensitive detection of D-amino acids in biological matrices, J. Sep. Sci. 32 (2009) 2305-23018; DOI: 10.1002/jssc.200900101.

2. R. Konno, H. Bruckner, A. D'Aniello, G. Fisher, N. Fujii and H. Homma, D-Amino Acids: A New Frontier in Amino Acid and Protein Research - Practical Methods and Protocols, Nova Science Publishers, New York 2008.

3. K. Hamase, A. Morikawa and K. Zaitsu, D-amino acids in mammals and their diagnostic value, J. Chromatogr. B 781 (2002) 73-91; DOI: 10.1016/S1570-0232(02)00690-6.

4. Y. Miyoshi, K. Hamase, Y. Tojo, M. Mita, R. Konno and K. Zaitsu, Determination of D-serine and D-alanine in the tissues and physiological fluids of mice with various D-amino-acid oxidase activities using two-dimensional high-performance liquid chromatography with fluorescence detection, J. Chromatogr. B 877 (2009) 2506-2512; DOI: 10.1016/j.jchromb.2009.06.028.

5. A. Morikawa, K. Hamase and K. Zaitsu, Determination of D-alanine in the rat central nervous system and periphery using column-switching high-performance liquid chromatography, Anal. Biochem. 312 (2003) 66-72; DOI: 10.1016/S0003-2697(02)00432-3. 
6. S. H. Snyder and C. D. Ferris, Novel neurotransmitters and their neuropsychiatric relevance, Am. J. Psychiatr. 157 (2000) 1738-1751; DOI: 10.1176/appi.ajp.157.11.1738.

7. H. Mori and R. Inoue, Serine racemase knockout mice, Chem. Biodivers. 7 (2010) 1573-1578; DOI: $10.1002 / \mathrm{cbdv} .200900293$.

8. H. Wolosker, E. Dumin, L. Balan and V. N. Foltyn, D-amino acids in the brain: D-serine in neurotransmission and neurodegeneration, FEBS J. 275 (2008) 3514-3526; DOI: 10.1111/j.1742-4658. 2008.06515.x.

9. H. Wolosker, A. D'Aniello and S. H. Snyder, D-aspartate disposition in neuronal and endocrine tissues: ontogeny, biosynthesis and release, Neuroscience 100 (2000) 183-189; DOI: 10.1016/ S0306-4522(00)00321-3.

10. A. D'Aniello, M. M. Di Fiore, G. H. Fisher, A. Milone, A. Seleni, S. D'Aniello, A. F. Perna and D. Ingrosso, Occurrence of $\mathrm{D}$-aspartic acid and $\mathrm{N}$-methyl-D-aspartic acid in rat neuroendocrine tissues and their role in the modulation of luteinizing hormone and growth hormone release, FASEB J. 14 (2000) 699-714.

11. S. Ishio, H. Yamada, M. Hayashi, S. Yatsushiro, T. Noumi, A. Yamaguchi and Y. Moriyama, D-aspartate modulates melatonin synthesis in rat pinealocytes, Neurosci. Lett. 249 (1998) 143146; DOI: 10.1016/S0304-3940(98)00414-5.

12. Y. Nagata, H. Homma, J. A. Lee and K. Imai, D-Aspartate stimulation of testosterone synthesis in rat Leydig cells, FEBS. Lett. 444 (1999) 160-164; DOI: 10.1016/S0014-5793(99)00045-9.

13. Y. Nagata, T. Fujiwara, K. Kawaguchi-Nagata, Y. Fukumori and T. Yamanaka, Occurrence of peptidyl D-amino acids in soluble fractions of several eubacteria, archaea and eukaryotes, Biochim. Biophys. Acta. 1379 (1998) 76-82.

14. H. Wang, H. Wolosker, J. F. Morris, J. Pevsner, S. H. Snyder and D. J. Selkoe, Naturally occurring free $\mathrm{D}$-aspartate is a nuclear component of cells in the mammalian hypothalamo-neurohypophyseal system, Neuroscience 109 (2002) 1-4; DOI: 10.1016/S0306-4522(01)00545-0.

15. L. Pollegioni, B. Langkau, W. Tischer, S. Ghisla and M. S. Pilone, Kinetic mechanism of D-amino acid oxidases from Rhodotorula gracilis and Trigonopsis variabilis, J. Biol. Chem. 268 (1993) 1385013857.

16. B. Curti, S. Ronchi and M. Pilone Simonetta, D- and L-amino acid oxidases, in Chemistry and Biochemistry of Flavoenzymes (Ed. F. Müller), CRC Press, Boca Raton (FL) 1992.

17. A. D'Aniello, A. Vetere and L. Petrucelli, Further study on the specificity of D-amino acid oxidase and D-aspartate oxidase and time course for complete oxidation of D-amino acids, Comp. Biochem. Physiol. B 105 (1993) 731-734; DOI: 10.1016/0305-0491(93)90113-J.

18. A. D'Aniello, G. Donofrio, M. Pischetola, G. Daniello, A. Vetere, L. Petrucelli and G. H. Fisher, Biological role of D-amino-acid oxidase and D-aspartate oxidase - Effects of D-amino acids, J. Biol. Chem. 268 (1993) 26941-26949.

19. N. Ercal, X. Luo, R. H. Matthews and D. W. Armstrong, In vitro study of the metabolic effects of D-amino acids, Chirality 8 (1996) 24-29.

20. K. B. Beckman and B. N. Ames, Oxidative decay of DNA, J. Biol. Chem. 272 (1997) 19633-19636; DOI: $10.1074 /$ jbc.272.32.19633.

21. B. S. Berlett and E. R. Stadtman, Protein oxidation in aging, disease, and oxidative stress, J. Biol. Chem. 272 (1997) 20313-20316; DOI: 10.1074/jbc.272.33.20313.

22. B. Halliwell and J. M. Gutteridge, Free radicals, lipid peroxidation, and cell damage, Lancet 2 (1984) 1095-1100; DOI: 10.1016/S0140-6736(84)91530-7.

23. T. Matsura, M. Kai, Y. Fujii, H. Ito and K. Yamada, Hydrogen peroxide-induced apoptosis in HL-60 cells requires caspase-3 activation, Free Radic. Res. 30 (1999) 73-83; DOI: 10.1080/107157 69900300081.

24. J. A. Barltrop, T. C. Owen, A. H. Cory and J. G. Cory, 5-(3-carboxymethoxyphenyl)-2-(4,5-dimethylthiazoly)-3-(4-sulfophenyl)tetrazolium, inner salt (MTS) and related analogs of 3-(4,5-dime- 
thylthiazolyl)-2,5-diphenyltetrazolium bromide (MTT) reducing to purple watersoluble formazans as cell-viability indicators, Bioorg. Med. Chem. Lett. 1 (1991) 611-614.

25. H. Aebi, Catalase in vitro, Methods Enzymol. 105 (1984) 105-121; DOI: 10.1016/S0076-6879(84) 05016-3.

26. K. J. Davies, Oxidative stress: the paradox of aerobic life, Biochem. Soc. Symp. 61 (1995) 1-31.

27. M. Sundaresan, Z. X. Yu, V. J. Ferrans, K. Irani and T. Finkel, Requirement for generation of $\mathrm{H}_{2} \mathrm{O}_{2}$ for platelet-derived growth factor signal transduction, Science 270 (1995) 296-299.

28. J. M. Mates, C. Perez-Gomez and I. Nunez de Castro, Antioxidant enzymes and human diseases, Clin. Biochem. 32 (1999) 595-603; DOI: 10.1016/S0009-9120(99)00075-2.

29. J. Soutourina, P. Plateau and S. Blanquet, Metabolism of D-aminoacyltRNAs in Escherichia coli and Saccharomyces cerevisiae cells, J. Biol. Chem. 275 (2000) 32535-32542.

30. O. Soutourina, J. Soutourina, S. Blanquet and P. Plateau, Formation of D-tyrosyl-tRNATyr accounts for the toxicity of D-tyrosine toward Escherichia coli, J. Biol. Chem. 279 (2004) 4256042565; DOI: 10.1074/jbc.M402931200.

31. M. L. Ferri-Fioni, M. Fromant, A. P Bouin, C. Aubard, C. Lazennec, P. Plateau and S. Blanquet, Identification in archaea of a novel D-Tyr-tRNA(Tyr) deacylase, J. Biol. Chem. 281 (2006) 2757527585.

32. L. M. Dedkova, N. E. Fahmi, S. Y. Golovine and S. M. Hecht, Enhanced D-amino acid incorporation into protein by modified ribosomes, J. Am. Chem. Soc. 125 (2003) 6616-6617; DOI: 10.1021/ ja035141q. 